\title{
Editoras Chefe:
}

Profa. Dra . Elaine Guglielmi Pavei Antunes - Engenheira Civil.

Prof. Me. Helena Somer Maccarini - Engenheira Civil

\section{Editores de Seção:}

Prof. Dr. Álvaro José Back - Engenheiro Agrônomo.

Prof. Me. Augusto Wanderlind - Engenheiro Civil

Prof. Dr. Glicério Trichês - Engenheiro Civil

Prof. Me. Helena Somer Maccarini - Engenheira Civil

Dados Internacionais de Catalogação na Publicação

Revista Técnico-Científica de Engenharia Civil UNESC [recurso eletrônico] - Vol. 1, n.1 (2018)- _ . Criciúma, SC : Unesc, 2018- .

Modo de acesso: 〈http://periodicos.unesc.net/engcivil/index>. Semestral.

1. Engenharia civil - Periódicos. 2. Materiais de construção Periódicos. 3. Estruturas (Construção civil) - Periódicos. 4. Engenharia sanitária e ambiental. 5. Construção civil Administração. I. Título.

CDD. $22^{\mathrm{a}}$ ed. 624.05

Bibliotecária Eliziane de Lucca Alosilla - CRB 14/1101

Biblioteca Central Prof. Eurico Back - UNESC 